\title{
Oküler yüzey hastalıklarında amniyon membran transplantasyonu endikasyonları ve sonuçları
}

\section{Indications and outcomes of amnion membrane transplantation in ocular surface diseases}

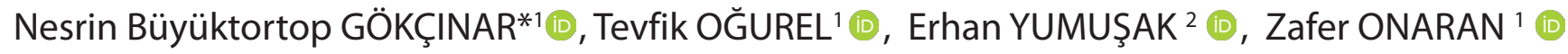

${ }^{1}$ Kırıkkale Üniversitesi, Tıp Fakültesi, Göz Hastalıkları Ana Bilim Dalı, Kırıkkale/TÜRKiYE

2 Sağlık Bilimleri Üniversitesi, Gülhane Eğitim ve Araştırma Hastanesi, Göz Hastalıkları Ana Bilim Dalı, Ankara/TÜRKiYE

\section{Öz}

Amaç: Oküler yüzey hastalıklarında amniyon membran transplantasyonunun etkinliğini değerlendirmek

Gereç ve Yöntemler: Ocak 2014-Ekim 2018 yılları arasında çeşitli oküler yüzey hastalıkları nedeniyle kliniğimizde amniyon membran transplantasyonu uygulanmış olan hastaların dosyaları retrospektif olarak incelendi. En az 3 ay takip edilen 25 hastanın 25 gözü çalışmaya dahil edildi.

Bulgular: Ortalama yaş 68,36 \pm 15,5 (29-93) yıl, ortalama takip süresi 19,48 \pm 17,33 (3-56) aydı. Amniyon membran transplantasyonu uygulama nedenleri büllöz keratopati $(n=6)$, enfekte kornea ülseri $(n=3)$, nörotrofik keratit ( $n=2)$, limbal yetmezlik $(n=2)$, desmatosel $(n=2)$, pterjium $(n=5)$, konjonktival kitle $(n=2)$, semblefaron ( $n=2)$ ve bir olguda limbal yetmezlik ile birlikte semblefarondu. Olguların sonuç görme keskinliğinde başlangıca göre anlamlı artış vardı $(p=0,018)$. Konjonktival kitle eksizyonu, semblefaron tamiri veya pterjium eksizyonu yapılan olgularda amniyon membran greft olarak kullanıldığında düzgün bir oküler yüzey iyileşmesi sağlanmış ve nüks oranı çok düşük izlenmiştir. Korneada önemli derecede incelmenin eşlik ettiği enfekte kornea ülseri, nörotrofik keratit ve desmatoseli olan olguların hepsinde perforasyon önlenmiştir.

Sonuç: Oküler yüzey hastalıklarının tedavisinde amniyon membran transplantasyonu etkili bir yöntemdir. Amniyon membran yüzey iyileşmesine katkıda bulunmakta ve derin kornea ülseri veya desmatoseli bulunan olgularda perforasyonu önlemeye yardımcı olmaktadır.

Anahtar kelimeler: amniyon membran; desmatosel; kornea; oküler yüzey; semblefaron.

Sorumlu Yazar*: Nesrin Büyüktortop GÖKÇINAR, Kıııkkale Üniversitesi, Tıp Fakültesi, Göz Hastalıkları Ana Bilim Dalı, Kırıkkale/TÜRKIYE E-posta: tortopn@kku.edu.tr

ORCID: 0000-0001-7795-5188

Gönderim: 06.12.2018 kabul: 17.03.2019

Doi: $10.18663 /$ tjcl.493014 


\section{Abstract \\ Aim: To evaluate the efficacy of amniotic membrane transplantation in ocular surface diseases.}

Material and Methods: The charts of patients who underwent amniotic membrane transplantation in our clinic for various ocular surface diseases between January 2014 and October 2018 were analyzed retrospectively. Twenty-five eyes of 25 patients with an at least 3 months of follow-up period were included into the study.

Results: The mean age was $68.36 \pm 15.5$ (29-93) years, and the mean follow-up period was $19.48 \pm 17.33$ (3-56) months. The indications for amniotic membrane transplantation were bullous keratopathy $(n=6)$, infected corneal ulcer $(n=3)$, neurotrophic keratitis $(n=2)$, limbal stem cell deficiency $(n=2)$, descematocele $(n=2)$, pterygium $(n=5)$. ), conjunctival lesion $(n=2)$, symblepharon $(n=2)$ and combined symblepharon and limbal stem cell deficiency in one of the cases. There was a significant increase in the final visual acuity of the patients with respect to the baseline $(p=0.018)$. When an amniotic membrane was used as an amniotic membrane graft in patients who underwent conjunctival tumour excision, symblepharon repair or pterygium excision, a smooth ocular surface healing was achieved and the recurrence rate was very low. Perforation was prevented in all cases with infected corneal ulcer, neurotrophic keratitis or descematocele accompanied by a significant thinning of the cornea.

Conclusion: Amniotic membrane transplantation is an effective method in the treatment of ocular surface diseases. Amnion membrane contributes to surface healing and helps to prevent perforation in patients with deep corneal ulcers or descematocele.

Key words: amnion membrane; descematocele; cornea; ocular surface; symblepharon.

\section{Giriş}

Amniyon membran plasentanın en iç kısmında yer alan ve kalınlığı $0.02-0.5 \mathrm{~mm}$ arasında değişen bir fetal membrandır. Epitel, bazal membran ve stromadan oluşmaktadır. Epitel tek sıra olarak kalın bazal membranın üzerinde yer alır. Yüzeyi düz ve parlaktır. Bazal membranın altında avasküler bir stroma bulunmaktadır. Amniyon membranda immünojenitesi düşük multipotent kök hücreler bulunmaktadır. Bazal membranda zengin ekstrasellüler matriks materyali mevcuttur. Tip I, III, IV, V, VII kollajen, fibronektin ve tip 1 ve laminin içermektedir. Bazal membranın epitel adezyonu, migrasyonu ve diferensiasyonunu hızlandırıı ve apoptozisi baskılayıcı özellikleri bulunmaktadır. Amniyon membranda epidermal büyüme faktörü, fibroblast büyüme faktörü, hepatosit gelişimi faktör, dönüştürücü büyüme faktörü ve antiproteinazlar bulunduğu gösterilmiştir. 3 Amniyon membranın anti-inflamatuar, anti-anjiojenik ve epitelizan etkileri bulunmaktadır. Aynı zamanda miyofibroblast diferensiasyonunu baskıladığı için anti-fibrotik etki göstermekte ve anti-inflamatuar etkisi ile birlikte skar oluşumuna karşı etkisi olduğu düşünülmektedir. Ayrıca bandaj kontakt lens etkisi ile ağrı kesici özelliği bulunmaktadır. Bu özelliklerinden dolayı oküler yüzey hastalıklarının tedavisinde umut vadetmektedir. Üstelik, HLA-A, B, C, DR antijeni içermemesi nedeniyle allogreft transplantasyonda immün yanıt oluşturmamaktadır [1].

Amniyon membran oftalmolojide ilk olarak 1940'da de Roth tarafından konjonktivada yanığa bağlı defektler için kullanılmıştır [2]. Ancak popüler hale gelmesi 1995 yılında Kim ve Tseng'in çalışmaları sonrasında olmuştur [3]. Günümüzde amniyon membran transplantasyonu (AMT) tıbbi tedaviye cevap vermeyen oküler yüzey bozuklukların tedavisinde kullanılmaktadır [4-7]. Oküler yüzey iyileşmesini hızlandırmak, perforasyonu önlemek, ağrıyı azaltmak ve oküler yüzey rekonstrüksiyonu sağlamak amaçlarıyla tercih edilmektedir.

Buçalışmada kliniğimizde AMT uygulama endikasyonlarıveamniyon membranın oküler yüzey iyileşmesi üzerine etkisi değerlendirilmiştir. Endikasyonların demografik etkenlerinin belirlenmesi ve klinik sonuçların literatürle karşılaştııılması amaçlanmıştır.

\section{Gereç ve Yöntemler}

Çalışma Kırıkkale Üniversitesi Girişimsel Olmayan Araştırmalar Etik Kurulu'ndan onay alınarak (2018.11.08) ve Helsinki Bildirgesi'nin ilkelerine uygun olarak yürütülmüştür. Ocak 2014 - Ekim 2018 tarihleri arasında Kıııkkale Üniversitesi Tıp Fakültesi Göz Hastalıkları Kliniğine başvuran ve oküler yüzey bozuklukları nedeniyle AMT uygulanan hasta kayıtları retrospektif olarak incelenmiştir. Hastalarda gönüllü rıza formları alınmıştır. Bu hastalardan düzenli olarak en az 3 ay takip edilen 25 tanesinin 25 gözü çalışmaya alınmıştır. Hastaların en iyi düzeltilmiş görme keskinliği Snellen eşeli ile ölçüldü. Oftalmolojik muayenede göz kapaklarından başlayarak, oküler yüzey, ön ve arka segment değerlendirildi. Göz içi basınç ölçümü ve arka segmentin aydınlanmadığı durumlarda oküler ultrasonografi yapıldı. Gerekli hastalarda göz yaşı fonksiyon testleri, kornea topografisi, optik koherens tomografi ile ön ve arka segment değerlendirmesi yapıldı. Tüm hastalardan AMT cerrahisi öncesi aydınlatılıı̧ onam belgesi alındı.

\section{Cerrahi teknik}

Amniyon membran Kim ve Tseng'in standart yöntemi ile hazırlandı [3,5]. Amniyon membran oküler yüzeye greft veya örtme tekniği ile ya da bunların kombinasyonu şeklinde 
uygulandı [1]. Olgularımızın 2 tanesi genel anestezi altında, diğerleri lokal anestezi altında opere edildi. Pterjium, konjonktiva tümörü ve semblefaronlarda lezyon eksize edildikten sonra doku defekti amniyon membran greft olarak kullanılarak kapatıldı. Greft konjonktivaya 8/0 poliglaktin ile sütüre edildi. Oküler yüzey tümör cerrahisinde korneaya uzanan lezyon alkol uygulayarak kaldırıldı.Lezyon eksizyonunu takiben serbest konjonktiva kenarlarına kriyoterapi uygulandı.

Kornea ülseri, büllöz keratopati, nörotrofik keratit gibi kornea lezyonlarında öncelikle mevcut gevşek nekrotik epitel bisturi yardımıyla debride edildi. Amniyon membran örtme tekniği ile korneayı tamamen kaplayacak şekilde limbusun 2-3 mm uzağındaki konjonktivaya 10/0 naylon ile devamlıolaraksütüreedildi.ileriderece kornea incelmesi olan üç olguda amniyon membran greft ve örtme tekniği kombine edilerek uygulandı. Korneaya greft uygulamak için debridmanı takiben membran ülser etrafındaki sağlam kornea dokusuna epitel/bazal membran tarafı yukarı bakacak şekilde 10/0 naylon ile tek tek sütüre edildi. Ardından daha geniş olan ikinci kat amniyon membran örtme tekniği ile tüm kornea ve limbusu kaplayacak şekilde 10/0 naylon sütürle yerleştirildi. Limbal kök hücre nakli ile birlikte AMT uygulanan olgularda membran örtme tekniği ile limbal greft üzerine yerleştirildi. Korneaya AMT yapılan tüm olgulara bandaj kontakt lens takıldı. Ameliyat sonrası tüm hastalara topikal antibiyotik (netilmisin veya tobramisin) ve deksametazon kombinasyonu ile prezervan içermeyen suni gözyaşı damlası verildi. Enfekte kornea ülserlerinde güçlendirilmiş vankomisin ve seftriakson kombinasyonu ile tedaviye başlandı. Klinik olarak fungal enfeksiyon şüphesi varsa topikal antifungal de tedaviye eklendi. Kültür antibiyogram sonuçlarına göre tedavi düzenlendi. Mikroorganizmanın saptanamadığı durumlarda klinik yanıta göre güçlendirilmiş antibiyotik dozu düzenlendi ve moksifloksasin monoterapisine geçildi. Hastaların postoperatif 1. gün, 1. hafta, 1. ay, 3. ay ve en son muayene bulguları dosyalarından elde edildi. Birinci ay kontrolünde sütürler alındı. Kontrollerde amniyon zarı, korneadaki incelmenin durumu, enfeksiyon veya inflamasyon varlığı değerlendirildi.

\section{Bulgular}

Yirmibeş olgunun 15'i (\% 60) erkek 10'u (\%40) kadın idi. Hastaların yaş ortalaması 68,36 \pm 15,5 (29-93) yıl olarak bulunmuştur. Ortalama takip süresi 19,48 \pm 17,33 (3-56) aydı. Olguların ameliyat edilen gözleri 10 kişide (\%40) sağ, 15 kişide (\%60) sol göz idi. AMT uygulama nedenleri, olguların demografik ve klinik özellikleri tablo-1'de verilmiştir. En sık sebep \%24 olguda büllöz keratopatiye bağlı şiddetli ağrı idi. Bu endikasyonu sırasıyla nüks pterjium, enfekte kornea ülseri, semblefaron, nörotrofik keratit, limbal yetmezlik, desmatosel, konjonktival kitle olguları takip etmekteydi. Tüm olgular ele alındığında AMT sonrası sonuç görme keskinliğinde başlangıca göre anlamlı artış vardı $(\mathrm{p}=0,018)$ (Tablo- 1$)$.

\begin{tabular}{|c|c|c|c|c|c|c|}
\hline Etiyoloji & $\begin{array}{l}\text { Sayı, n } \\
(\%)\end{array}$ & Yaş, yıl & $\begin{array}{l}\text { Kadın / } \\
\text { Erkek } \\
\text { Dağılımı }\end{array}$ & Takip süresi, ay & $\begin{array}{l}\text { Preoperatif görme } \\
\text { keskinliği }\end{array}$ & $\begin{array}{l}\text { Sonuç görme } \\
\text { keskinliği }\end{array}$ \\
\hline $\begin{array}{l}\text { Büllöz kera- } \\
\text { topati }\end{array}$ & $6(\% 24)$ & $73,17 \pm 23,05(29-93)$ & $2 / 4$ & $14,50 \pm 13,86(3-36)$ & $0,031 \pm 0,032(0-0,08)$ & $0,031 \pm 0,032(0-0,08)$ \\
\hline Pterjium & $5(\% 20)$ & $61,80 \pm 12,57(44-77)$ & $4 / 1$ & $19,80 \pm 17,18(6-48)$ & $0,62 \pm 0,41(0-1)$ & $0,64 \pm 0,40(0-1)$ \\
\hline $\begin{array}{l}\text { Enfekte } \\
\text { kornea ülseri }\end{array}$ & $3(\% 12)$ & $73,30 \pm 6,02(67-79)$ & $0 / 3$ & $21,33 \pm 28,36(3-54)$ & $0,003 \pm 0,004(0-0,008)$ & $0,017 \pm 0,02(0-0,05)$ \\
\hline $\begin{array}{l}\text { Nörotrofik } \\
\text { keratit }\end{array}$ & $2(\% 8)$ & $69,00 \pm 2,82(67-71)$ & $1 / 1$ & $10,50 \pm 6,36(6-15)$ & $0,03 \pm 0,00(0,03-0,03)$ & $0,16 \pm 0,19(0,03-0,3)$ \\
\hline Desmatosel & $2(\% 8)$ & $78,00 \pm 8,48(72-84)$ & $1 / 1$ & $34,00 \pm 31,11(12-56)$ & $0,0005 \pm 0,0007(0-0,001)$ & $0,01 \pm 0,005(0,008-0,016)$ \\
\hline $\begin{array}{l}\text { Konjonktival } \\
\text { kitle }\end{array}$ & $2(\% 8)$ & $84,50 \pm 0,70(84-85)$ & $1 / 1$ & $13,80 \pm 14,84(3-24)$ & $0,15 \pm 0,07(0,1-0,2)$ & $0,15 \pm 0,07(0,1-0,2)$ \\
\hline $\begin{array}{l}\text { Limbal yet- } \\
\text { mezlik }\end{array}$ & $2(\% 8)$ & $63,00 \pm 8,48(57-69)$ & $1 / 1$ & $17,00 \pm 7,00(12-22)$ & $0,15 \pm 0,20(0,01-0,30)$ & $0,22 \pm 0,24(0,05-0,40)$ \\
\hline Semblefaron & $2(\% 8)$ & $48,00 \pm 8,48(42-54)$ & $0 / 2$ & $42,00 \pm 8,48(36-48)$ & $0,90 \pm 0,14(0,8-1)$ & $0,90 \pm 0,14(0,8-1)$ \\
\hline $\begin{array}{l}\text { Limbal } \\
\text { yetmezlik ve } \\
\text { semblefaron }\end{array}$ & $1(\% 4)$ & 56 & 1 & 3 & 0,001 & 0,001 \\
\hline Toplam & $\begin{array}{c}25 \\
(\% 100)\end{array}$ & $68,36 \pm 15,49(29-93)$ & $10 / 15$ & $19,48 \pm 17,33(3-56)$ & $0,23 \pm 0,35(0-1)$ & $0,25 \pm 0,35 *(0-1)$ \\
\hline
\end{tabular}




\section{Kornea hastalıklarındaki sonuçlar}

Büllöz keratopatide keratoplasti yapılamayan veya görme prognozu düşük olan, şiddetli ağrı, batma ve fotofobi şikayetleri nedeniyle terapötik kontakt lens (TKL) kullanan büllöz keratopatili 6 hastada AMT'den sonra ağrıda azalma oldu. Olguların \% 83.3'ünde tamamen epitelizasyon gerçekleşti. Olguların \%66,6'sında TKL kullanma ihtiyacı kalmazken, \%34.4'ü ağrı tamamen ortadan kalkmadığı için TKL kullanmaya devam etti. Epitel defekti kapanmayan ve ağrısı geçmeyen bir hastaya tarsorafi yapıldı.

Nörotrofik keratit nedeniyle 2 hastaya greft ile kombine örtme tekniği uygulandı (Resim-1). Herpetik keratite bağlı nörotrofik ülseri olan hastada epitelizasyon gerçekleşti. Diğer olguda epitel defekti ve stromadaki incelme alanı küçülmesine rağmen defekt tamamen kapanmadı. Olgu otolog serum ve suni gözyaşı tedavisi ile takip edildi.

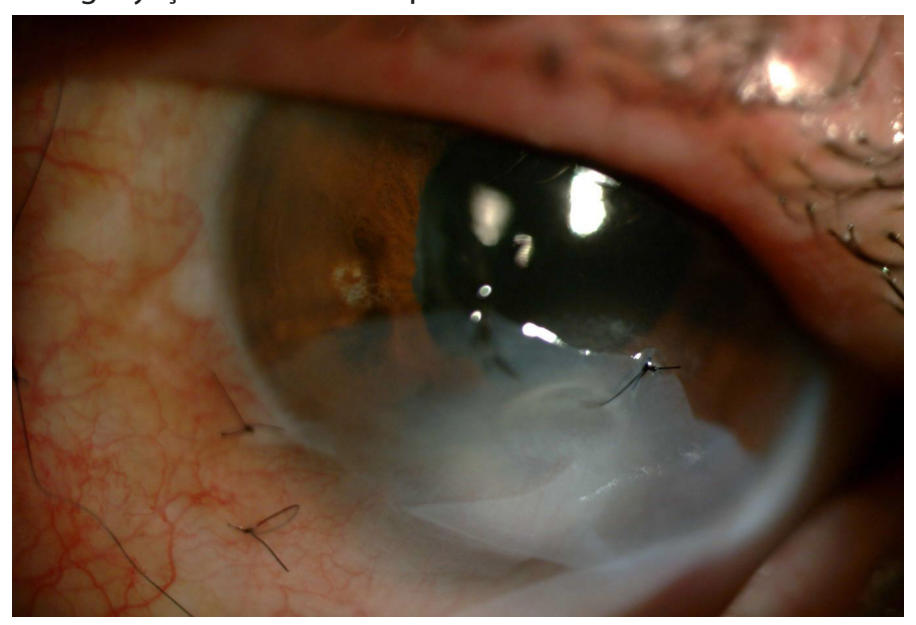

Resim-1. Nörotrofik keratit nedeniyle korneanın inferior kadranında incelmesi olan ve amniyon membranın greft ile kombine örtme tekniği ile uygulandığı olgu. Kornea üzerinde greft ve konjonktiva üzerinde amniyon membran ve sütürler izlenmekte.

Enfekte kornea ülseri olan 3 olguya AMT uygulandı. Bu olgular ülserin derin olduğu ve perforasyon riski olan olgulardı. Bir olguda polimikrobiyal enfeksiyon tespit edildi: kültürde Pseudomonas aeruginosa üremesi oldu ve direk bakıda mantar hifleri görüldü. Daha önce dış merkezde antibiyotik tedavisi başlanan 2 olguda etken gösterilemedi. Üç olguya da AMT örtme tekniği ile uygulandı ve topikal fortifiye antibiyotik tedavisi verildi. Birinci olguda ilk operasyondan 2 hafta sonra amniyon membranın erimesi ve bu süreçte epitelizasyonun tamamlanmaması nedeniyle ülser üzerine greft ile kombine amniyon örtme uygulandı. Bu operasyondan yaklaşık 3 hafta sonra tamamen epitelizasyon sağlandı. İkinci hastada eşlik eden ektropiyon farklı bir seansta düzeltildi. Keratit odağı geriledi ve epitel defekti tamamen kapandı. Ancak, hasta 4 ay sonra yeniden keratit ile başvurdu. Bu sefer sadece topikal antibiyotik tedavisi ile düzelme sağlandı. Üçüncü olguda epitelizasyon sağlandı ve keratit odağı kayboldu.

Perforasyon riski bulunan iki desmatosel olgusuna acil olarak AMT uygulandı. íki olguda da etiyolojide enfekte kornea ülseri düşünüldü ancak mikrobiyolojikincelemedeetken gösterilemedi. Olgulara fortifiye antibiyotik tedavisi ve örtme tekniği ile iki kat amniyon uygulandı (Resim-2 ve Resim-3). İkinci olguda amniyonun iki hafta sonra erimesi üzerine greft ile kombine örtme tekniği ile ikinci kez AMT uygulandı. İki olguda da AMT ile perforasyon önlendi ve ön kamara oluştu. Olgularımız ileri yaş ve sistemik sorunlarından dolayı penetran keratoplasti cerrahisini kabul etmediler. Birinci olgunun 5 yıla yakın takip süresinde nüks görülmedi. İkinci olgu korneadaki incelme düzeldikten 4 ay sonra tekrar keratit ile başvurdu, bu sefer medikal tedavi ile düzelme sağlandı. Takiplerde korneada incelme izlenmedi.

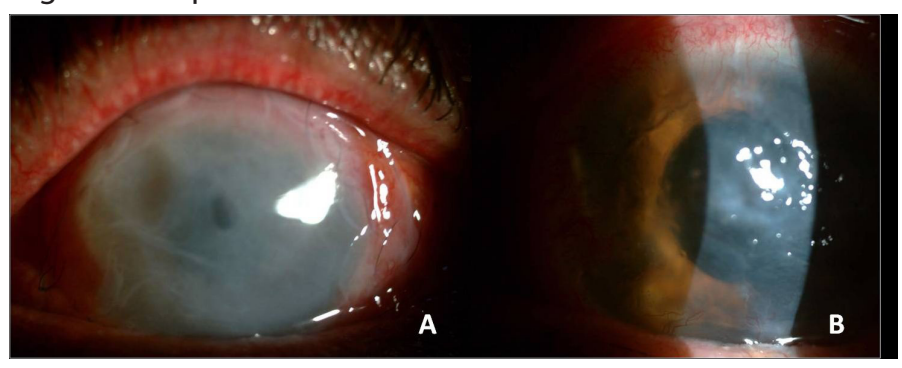

Resim-2. Desmatosel nedeniyle iki kat amniyon örtme uygulanan olgunun postoperatif 1. gün (A) ve 3. ay (B) görüntüsü.

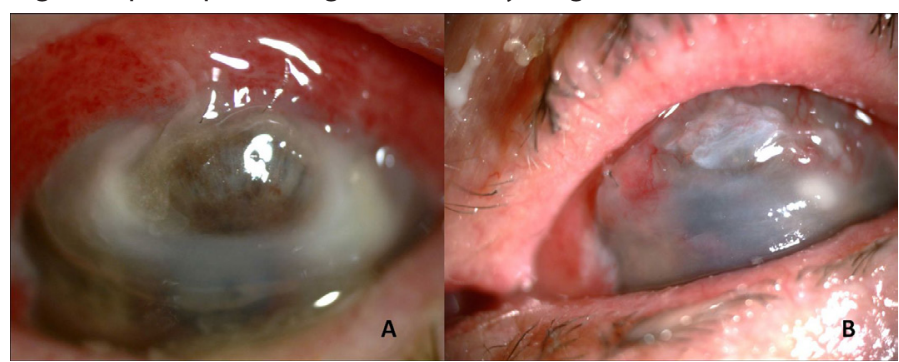

Resim-3. Desmatosel nedeniyle iki kat amniyon membran uygulanan diğer olgunun preoperatif $(A)$ ve postoperatif 1.gün (B) görüntüsü.

Limbal yetmezlik düşündüğümüz 3 olgumuz vardı. Alkali yanık sekeli olarak limbal yetmezlik ve semblefaronu olan hasta sağlam gözünden limbal ototgreft alınmasını kabul etmediği için bu göze semblerafon tamiri ile birlikte AMT uygulandı. Limbal kök hücre nakli yapılamadı. Geçirilmiş fasyal paraliziye bağlı ekspojur keratopatisi olan olguda kornea alt yarısındaki lökom yüzeyel keratektomi ile temizlenerek, limbal otogreft ve AMT uygulandı (Resim-4). Olgu 4 ay medikal tedavi ve TKL ile takip edildi. Epitel defekti küçüldü ancak tam olarak kapanmadı. Bunun üzerine ikinci kez AMT 
uygulandı. TKL ve medikal tedavi ile 2 ay sonra epitel defekti kapandı ve vaskülarizasyon azaldı. Üçüncü hastada etiyolojisi saptanamayan bir limbal yetmezlik mevcuttu. Limbal otogreft ve AMT ile epitelizasyon sağlandı, periferik vaskülarizasyon geriledi ancak takip eden aylar içerisinde vaskülarizasyon ve konjonktivalizasyon oluştu, hastaya subkonjonktival antiVEGF (vasküler endotelyal büyüme faktörü) enjeksiyonu uygulandı ve vaskülarizasyon bir miktar geriledi.

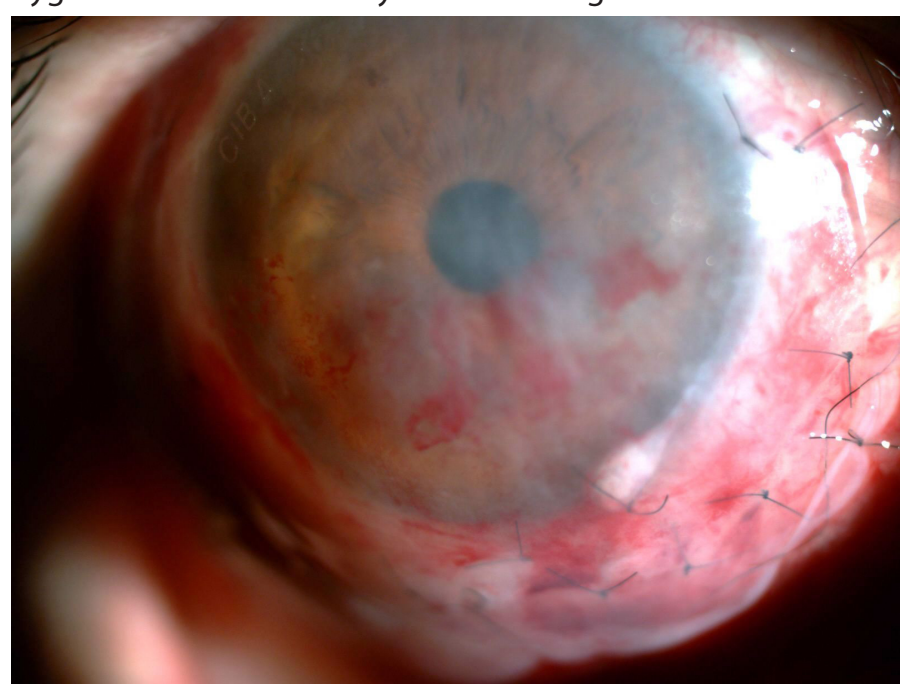

Resim-4. Limbal yetmezlik nedeniyle limbal otogreft ile kombine amniyon örtme uygulanan olgunun postoperatif 1. gün görüntüsü.

\section{Konjonktiva hastalıklarındaki sonuçlar}

Konjonktival kitle nedeniyle oküler yüzey tümör cerrahisi uygulanan ve greft olarak AMT uygulanan kullanılan 2 olguda da epitelizasyon sağlandı. Bu lezyonların histopatolojik tanıları konjonktival intraepitelyal neoplazi olarak rapor edildi. Olguların hiçbirinde nüks görülmedi.

Semblefaronu olan 3 hastamız vardı. nedenleri termal yanık $(n=1)$, mekanik travma $(n=1)$ ve alkali yanık $(n=1)$ idi. Mekanik travmaya bağlı semblefaron olgusunda bakış kısıtlıı̆ı ve diplopi mevcuttu. Üç olguda da semblefaron serbestleştirildikten sonra AMT uygulandı ve forniks oluşturma sütürleri atıldı. Olgularımızın birindeki bakış kısıtlılığı düzeldi. Termal yanık olgusuna eşlik eden entropion için ikinci aşamada kapak cerrahisi uygulandı. Limbal yetmezliğin eşlik ettiği alkali yanık olgusu, sağlam gözünden limbal ototgreft alınmasını kabul etmediği için bu hastaya semblerafon tamiri ile birlikte AMT uygulandı. Vaskülarizasyonda gerileme izlendi. Semblefaron olgularının hiç birinde nüks görülmedi.

Nüks pterjiumu olan 4 olgu ile primer pterjiumu olan ancak glokom nedeniyle ileride gerekebilecek filtran cerrahi açısından konjonktivanın korunmasına karar verilen 1 olguda pterjium cerrahisinde konjonktiva defekti AMT ile kapatıldı. Tüm olgularda hızlı bir epitel iyileşmesi sağlandı. Olguların \%80'inde nüks görülmedi.

\section{Tartışma}

Amniyon membran anti-inflamatuar, anti-anjiyojenik, antifibrotik, anti-mikrobiyal, ağrıyı azaltıcı ve epitelizasyonu hızlandırıcı etkilerinden dolayı oküler yüzey hastalıklarının tedavisinde kullanılmaktadır. İyileşmeyen kornea erozyonları, korneada erime, desmatosel, nörotrofik keratit, büllöz keratopati, kimyasal yanık önemli AMT endikasyonlarıdır [5]. Ayrıca, pterjium cerrahisinde, konjonktivada tümör eksizyonları sonrası veya semblefaron tamirinde, limbal yetmezlikte limbal kök hücre nakli ile kombine edilerek uygulanmaktadır [1,5,8]. Farklı oküler yüzey hastalıklarının tedavisinde uygulanan AMT'nin başarısı hastalık etiyolojisine ve uygulanan tekniğe göre değişebilmektedir.

Büllöz keratopatide AMT iki farklı teknikle uygulanmaktadır. Birinci yöntem Letko ve ark. tarafından tarif edilen epitel debridmanı sonrası klasik örtme yöntemidir [9]. Diğer yöntem ise ülkemizde Altıparmak ve ark. tarafından uygulanan sırasıyla trepanla işaretleme, epitel debridmanı ve stromal cep oluşturma ardından amniyon membranın stromal ceplere sütürasyonu basamaklarından oluşan stromal cep tekniğidir [10]. Bazı serilerde epitel debridmanı ile beraber stromal ponksiyon veya fototerapötik keratektomi ile kombine yöntemler bildirilmiştir [10]. Büllöz keratopatide farklı AMT yöntemleri ile epitelizasyon oranı \%55,5 ile \%100 arasında, ağrıyı giderme oranı \%22.2 ile \%100 arasında bildirilmiştir. Bizim çalışmamızda ağrıyı giderme oranı klasik örtme yöntemi ile bildirilen \%61.1 oranına benzer şekilde \%66.6 idi [10]. Korneanın tamamen epitelize olma oranı da literatürde klasik yöntemle bildirilen \%88,9 oranına benzer şekilde \%83,3 idi [10]. Stromal ceplere sütürasyon tekniği ile klasik örtme yöntemine göre özellikle ağrıyı giderme konusunda daha başarılı sonuçlar bildirildiği için ileri çalışmalarda bu yöntemin tercih edilebileceğini düşünmekteyiz.

Acer ve ark. nörotrofik keratitte AMT ile \%63 olguda epitelizasyon gerçekleştiğini ve ortalama 7 aylık takip süresinde nüks görülmediğini bildirmişlerdir [5]. Amniyon membran içerdiği laminin, fibronektin, fibroblast büyüme faktörü ve hepatosit büyüme faktörü gibi ajanlar ile kornea epitel iyileşmesine katkıda bulunmakta ve stromanın proliferasyon ve diferensiasyonunu düzenlemektedir. Anti inflamatuar ve bandaj kontakt lens etkisi ile oküler yüzeyi korumaktadır [1]. Amniyon membranın bu özellikleri ile nörotrofik keratit tedavisinde rolü 
olduğu düşünülmektedir. Ancak, nörotrofik keratitte etiyolojik faktörlerin ortadan kaldırılamaması, eşlik eden limbal kök hücre yetmezliği ve kuru göz tedavi başarısını düşüren faktörler olarak öne sürülmektedir [5]. Serimizde nörotrofik keratiti olan olguların birinde AMT ile epitelizasyon sağlanırken diğerinde yeterli sonuç alınamadığı için diğer tedavi yöntemleri uygulandı.

Acer ve ark. 14 mikrobiyal keratit olgusunın \%85'inde AMT ile düzelme bildirmişlerdir [5]. Benzer şekilde Cindarik ve ark. \%92 enfekte kornea ülseri olgusunda AMT ile başarılı sonuç elde etmişlerdir [6]. Yusufoğlu ve ark. bakteriyel keratite bağlı kornea ülseri olgularının tamamında, herpetik keratite bağlı kornea ülserlerinin ise büyük kısmında AMT ile epitelizasyonun ortalama 22 günde sağlandığını bildirmişlerdir. Bu çalışmada amniyon membranın inflamasyonu baskılamak, perforasyonu önlemek ve epitelizasyonu sağlamak açısından etkili olduğu, aynı zamanda anlamlı görme artışı sağladığı bildirilmiştir [12].

Özdemir ve ark. perfore olan veya perfore olmayan desmatosel tedavisinde AMT uyguladıkları olguların \%73'ünde başarılı sonuç bildirmişlerdir [13]. Bizim olgularımızda da AMT ile perforasyon önlenmiş ve ön kamara oluşmuştur. Desmatosel tedavisinde amniyon membran, anti-inflamatuar etki yanı sıra mekanik destek sağlayarak perforasyonu önleyebilmekte ve daha sonra keratoplasti uygulamak için zaman kazandırmaktadır [13].

Uçakhan ve ark. kimyasal yanık sekeline bağlı total limbal kök hücre yetmezliği olan 3 olgunun hepsinde AMT ile kombine edilen limbal otogreft transplantasyonu ile başarılı sonuçlar bildirmişlerdir [14]. Ertan ve ark. AMT ile birlikte tarsorafi uyguladıkları ekspojur keratopatiye bağlı limbal yetmezliği olan bir olguda epitel defektinin kapandığını ve görme keskinliğinin arttığını bildirmişlerdir [15]. Bizim olgularımızda limbal otogreft üzerine AMT uygulanmıştır. Olgularımızın birine ikinci kez AMT uygulayarak diğerine ise daha sonra antiVEGF enjeksiyonu yaparak olumlu sonuçlar elde edebildik. Limbal kök hücre naklinde kültüre edilmiş limbal epitel hücre transplantasyonu veya basit limbal epitel transplantasyonu adı verilen limbus greftinin küçük parçalara halinde fibrin yapıştırıcı ile göz yüzeyine yayılarak amniyon membran ile örtüldüğü SLET tekniği gibi yeni yöntemlerle daha başarılı sonuçlar bildirilmektedir [16]. Durak ve ark. modifiye teknikle amniyon membran üzerinde kültüre edilmiş limbal epitel hücre transplantasyonu uyguladıkları tüm olgularda görme artışı bildirmişlerdir. Bu çalışmadaki 5 olgudan 3 tanesine takiplerde vaskülarizasyon ve konjonktivalizasyon gelişmesi üzerine ek olarak bizim olgumuzda olduğu gibi subkonjonktival ve/veya topikal bevacizumab uygulamışlardır [17].
Konjonktivada kitle lezyon eksizyonu sonucu ortaya çıkan doku defektlerinin tamirinde amniyon membranın greft olarak kullanımı ile ilgili başarılı sonuçlar bildirilmiştir. AMT, hastanın kendi konjonktiva dokusunun korunması, kozmetik avantajları ve yara iyileşmesini kolaylaştırıcı özellikleri ile tümör eksizyonu sonrası oküler yüzey rekonstrüksiyonunda tercih edilmektedir [5].

Farklı oküler yüzey hastalıklarına bağlı olarak oluşmuş olan semblefaron tamirinde AMT etkili bir yöntemdir. Amniyon membranın semblefaron cerrahisinde greft olarak kullanılması fibroblast aktivasyonunu önleyici etkisinden dolayı skar oluşumuna karşı avantaj sağlamaktadır. Solomon ve arkadaşlarının AMT uyguladıkları 17 gözlük serilerinde \%70 olguda fornikste tam düzelme izlenmiştir. Kısmi düzelme olan veya nükseden olgularda etiyolojinin otoimmün hastalık veya nüks pterjium olduğu bildirilmiştir [18]. Hamal ve arkadaşları AMT uyguladıkları 57 semblefaron olgusunun \%12'sinde nüks nedeniyle ikinci kez cerrahi uygulamışlardır [19]. Tüm olgularda AMT ile oküler konfor artmıştır. Bizim olgularımızın tamamında forniks oluşturulmuş ve ortalama 37 aylık takip süresinde nüks görülmemiştir.

Pterjium cerrahisinde amniyon membran anti inflamatuar ve skar önleyici etkileri nedeniyle greft olarak kullanılmaktadır. Nüks oranı çıplak sklera tekniğine göre çok düşüktür. Ancak konjonktival otogreft tekniğine göre bir miktar yüksektir [20]. Cochrane veritabanından yapılan güncel bir sistematik derlemede pterjium cerrahisinde konjonktival otogreft sonrası nüks oranları 3.3\%-16.7\% iken amniyon membran greft sonrası nüks oranları $6.4 \%-42.3 \%$ arasında değişmektedir [20]. Ancak bu derlemede mitomisin-C gibi adjuvan kullanımı ve pterjiumun primer veya nüks olması gibi faktörler dikkate alınarak ileri bir analiz yapılmamıştır. Amniyon membranın konjonktiva otogreftine avantajı bulber konjonktivanın korunması, mitomisin-C'ye avantajı ise sklera incelmesi gibi ciddi komplikasyonlara neden olmamasıdır. Bizim olgularımızın bir tanesinde glokom nedeniyle ileride gerekebilecek filtran cerrahi için konjonktivayı korumak, diğer nüks pterjium olgularında ise daha önce otogreft alınmış olan üst bulber konjonktiva bölgesini korumak amacıyla AMT uygulanmıştı.

Özet olarak çalışmamızda AMT konjonktiva hastalıklarında greft olarak uygulandığında çok başarılı sonuçlar elde edilmiştir. Kitle eksizyonu, semblefaron tamiri ve pterjiumda eksize edilen doku AMT ile kapatıldığında hem düzgün bir oküler yüzey iyileşmesi sağlamış, hem de pterjiumlu bir olgu dışında nüks görülmemiştir. Korneada önemli derecede incelmenin eşlik ettiği enfekte kornea ülseri, nörotrofik keratit ve desmatoseli olan olguların hepsinde AMT ile perforasyon 
önlenmiştir. Nörotrofik keratit olgularında kornea ülserinin derinliğinde azalma olmasına rağmen lezyonun tam olarak kapanmasında başarı diğer olgulara göre daha düşük olmuştur. Bunda nörotrofik keratitte etiyolojik faktörlerin ortadan kaldırılamamasının rol oynadığını düşünmekteyiz. Limbal kök hücre yetmezliğinde AMT, limbal kök hücre nakli ile beraber uygulandığında etkili olabilmektedir. Günümüzde geliştirilmekte olan yeni limbal kök hücre nakli yöntemleri ile bu başarının artması mümkün olacaktır.

\section{Sonuç}

Amniyon membran hazırlaması kolay ve düşük maliyetli bir biyolojik materyaldir. Oküler yüzey hastalıklarında AMT ile elde edilen başarıı sonuçların bu yöntemin daha yaygın uygulanması için ümit verici olduğunu düşünmekteyiz.

\section{Çıkar çatışması / finansal destek beyanı}

Bu yazıdaki hiçbir yazarın herhangi bir çıkar çatışması yoktur. Yazının herhangi bir finansal desteği yoktur.

\section{Kaynaklar}

1. Jacop S, Agarwal A: Amniotic membrane transplantation. In: Copeland RA, Afshari NA (eds). Copeland and Afshari's Principle and Practice of Cornea, 1st ed. New Delhi: Jaypee Brothers Medical Publishers; 2013: 1028-1038.

2. de Roth A. Plastic repair of conjunctival defects with fetal membranes. Arch Ophthalmol 1940; 23: 522-55.

3. Kim JC, Tseng SC. Transplantation of preserved human amniotic membrane for surface reconstruction in severely damaged rabbit corneas. Cornea 1995; 14: 473-84.

4. Azuara-Blanco A, Pillai CT, Dua HS. Amniotic membrane transplantation for ocular surface reconstruction. $\mathrm{Br} J$ Ophthalmol 1999; 83: 399-402.

5. Acer S, Yalnız-Akkaya Z, Yalçın-Tök Ö, Burcu A, Örnek F. Kornea ve Konjonktiva Hastalıklarında Amniyon Membran Transplantasyonu. Türkiye Klinikleri J Med Sci 2012; 32: 609-17.

6. Cindarik D, Yağmur $M$, Şekeroğlu HT, Erdem E. Oküler Yüzey Rekonstrüksiyonunda amniyon zarı uygulamaları: Klinik özellikler ve tedavi sonuçları. Turk J Ophthalmol 2012; 42: 177-82.

7. Yildiz EH, Nurozler AB, Ozkan Aksoy N, Altiparmak UE, Onat M, Karaguzel $\mathrm{H}$. Amniotic membrane transplantation: indications and results. Eur J Ophthalmol 2008; 18: 685-90.

8. Gündüz K, Uçakhan OO, Kanpolat A, Günalp I. Nonpreserved human amniotic membrane transplantation for conjunctival reconstruction after excision of extensive ocular surface neoplasia. Eye 2006; 20: 351-57.
9. Letko E, Stechschulte SU, Kenyon KR et al. Amniotic membrane inlay and overlay grafting for corneal epithelial defects andstromal ulcers. Arch Ophthalmol 2001; 119: 659-63.

10. Altiparmak UE, Oflu Y, Yildiz EH, et al. Prospective comparison of two suturing techniques of amniotic membrane transplantation for symptomatic bullous keratopathy. Am J Ophthalmol 2009; 147: 442-46.

11. SonmezB,Kim BT,Aldave AJ.Amniotic membranetransplantation with anterior stromal micropuncture for treatment of painful bullous keratopathy in eyes with poor visual potential. Cornea 2007; 26: 227-29.

12. Yusufoğlu EE, Burcu A, Yalnız-Akkaya Z, Örnek F. Herpetik ve Bakteriyel Keratitlerde Amniyotik Membran Transplantasyonu. Turk J Ophthalmol 2013; 43: 229-35.

13. Özdemir ES, Burcu A, Akkaya ZY, Ornek F. Surgical outcomes of perforated and unperforated corneal descemetocele. Int Ophthalmol 2018; 38: 327-35.

14. Uçakhan ÖÖ, Köklü G, Firat E. Oküler yüzey rekonstrüksiyonunda amniotik membran transplantasyonu. TKlin Oftalmoloji 2001; 10: 199-205.

15. Ertan A, Akova YA, Aydın P. Oküler yüzey bozukluğu tedavisinde amniyotik membran transplantasyonu. T Oft Gaz 2002; 32:902-908.

16. Haagdorens M, Van Acker SI, Van Gerwen V et al. Limbal Stem Cell Deficiency: Current Treatment Options and Emerging Therapies. Stem Cells Int 2016; 2016: 9798374.

17. Durak I, Selver ÖB, Erdal E, Kunter İ, Söylemezoğlu ZÖ, Wolosin JM. Ocular Surface Reconstruction with Cultivated Limbal Epithelial Cells in Limbal Stem Cell Deficiency: One-year Followup Results. Turk Oftalmol Derg 2012; 42: 172-76.

18. Solomon A, Espana EM, Tseng SC. Amniotic membrane transplantation for reconstruction of the conjunctival fornices. Ophthalmology 2003; 110: 93-100.

19. Hamal D, Singh SK, Lamichhane B, Sharma A, Anwar A, Mahaseth V. Amniotic membrane transplantation: Current indications in a tertiary eye hospital of eastern Nepal. Nepal J Ophthalmol 2016; 8: 151-60.

20. Clearfield E, Hawkins BS, Kuo IC. Conjunctival Autograft Versus Amniotic Membrane Transplantation for Treatment of Pterygium: Findings From a Cochrane Systematic Review. Am J Ophthalmol 2019; 182: 8-17. 